\title{
The Place of Written Burmese and Mon in Burma's Early History
}

IF THE PAGÁN SCRIPT was not derived from the Dvāravatī script, but indirectly from the earlier scripts of either Vanavasi or Andhra via the Pyū, there should be evidence in the epigraphic record that Old Burmese writing preceded Old Mon writing in Burma. And indeed, this is what the evidence actually shows. However, since it runs directly counter to the Mon Paradigm's claims that written Old Mon preceded and was the source for written Old Burmese, the issue has become thoroughly obfuscated in Pagán-period minutiae. This chapter, therefore, attempts to plow through that obfuscation and clarify the place of written Old Burmese and Old Mon in Burma's history.

\section{The Myazedi Issue}

In 1886-1887 two nearly duplicate multilingual stone pillars of the Myinkaba Kubyaukgyi temple, ${ }^{1}$ popularly known as the Myazedi Inscriptions, were discovered at Myinkaba village near Pagán by Forchhammer, the director of archaeology. The stones, conventionally dated to approximately 1112-1113 AD, ${ }^{2}$ were inscribed on four sides, all apparently written in the same script, but each representing a different language, and all more or less conveying the same message. For the first and only time in Burma's history, Pyū, Pali, Burmese, and Mon were recorded (presumably simultaneously), capturing an extremely important moment in Burma's history: the crystallization of Burmese culture in the synthesis called the kingdom of Pagán, a polity which in turn laid the critical foundations for what was to become modern Burma. Yet precisely how that moment was reached, the issue being addressed in this book, is a matter of dispute.

The heart of the Myazedi Issue concerns the relative chronology of written Burmese versus written Mon in Burma. Whereas it is agreed by nearly all that King Kyanzittha's Old Mon inscription of 1093 found at Prome is the first, dated evidence of written Old Mon in the country, ${ }^{3}$ the first evi- 
dence for written Burmese is said to have been the Myazedi Inscriptions of c. 1112-1113. ${ }^{4}$ However, the latter conclusion was reached before having conducted any linguistic analysis on the comparative chronologies of written Old Burmese and Old Mon in Burma based on original and securely dated inscriptions, and as a result is totally arbitrary and self-serving. ${ }^{5}$ It is one of the most egregious myths in Burma Studies still held to be true by scholars of Southeast Asia today. By that single assertion-that the Burmese found on the Myazedi is the first evidence of its written form-the Mon Paradigm scholars "established" that written Old Mon was older than written Old Burmese without having to prove it. Thus whenever Old Burmese inscriptions were found dated prior to 1112-1113-and the Mon Paradigm scholars knew of several, as I will show-they were automatically declared unreliable and impossible. From the start, then, Old Burmese never had a chance of being examined outside the Mon Paradigm's theoretical prejudices.

Consequently, all analyses of Burmese orthography presumed that the version on the Myazedi was the oldest form, the one from which all others were ultimately derived. Not only did this make orthography the ultimate litmus test for deciding chronology (and therefore the evolutionary scheme for Burmese), but the Burmese script on the Myazedi also became the standard by which all other written Burmese at Pagán was measured. All this, not coincidentally, made it consistent with the underlying assumption of the Mon Paradigm that Mon civilization preceded Burman in every case. Once again, premise had become proof.

The Myazedi Inscriptions state that the king mentioned on them, Śri Tribhuvanāditya Dhammarāja-assumed to be Kyanzittha-was king 1,628 years after the Buddha's parinibbānna. ${ }^{6}$ This should correspond to 1084 AD, if the Burmese tradition of $544 \mathrm{BC}$ is used for calculating the date of the parinibbānna. But if another calculating era, such as that used in Thailand was intended, or if the date was meant to represent a yet-to-be-completed year, then the reign of this king must be changed accordingly and calculated with 543 BC (hence, to 1083 AD). Since the inscriptions also state that the king had ruled for twenty-eight years, it means the original of the two Myazedi stones had to have been inscribed thereafter, dating the Myazedi to 1111 , not 1112, as conventionally given. The second stone with its newerlooking script could, of course have been inscribed much later than either date, an issue not yet discussed in Burma Studies. The inscriptions were thought to have been the product of Prince Rājakumār, the king's son by the chief queen, Trilokawatamsakādewī, both of whom are mentioned on the stones.

In any case, the assumption that the Old Burmese script on the Myazedi is its oldest sample subsequently became the analytical framework for devel- 
oping an evolutionary scheme of written Burmese at Pagán. In this scenario, Old Mon was automatically assumed to be the starting point, followed by Old Burmese, which then went through its prescribed transformations. The scheme envisioned a three-phase evolution that went from "Archaic" to "Standard Old" to "Modern" Burmese. The differences between Archaic and Standard Old Burmese-the pertinent comparison here-were determined largely by the internal inconsistencies of spelling in Archaic Burmese, which was considered "haphazard and diverse." 7 The language was thought to have become standardized only by the mid-twelfth century. Yet this "standardization" is based on a single inscription of Princess (or Queen) Ajāwlat ("Queen's Burmese," as it were), erected in 1165, that showed extraordinary consistency of spelling and other refinements.

Thus Ba Shin, then an assistant as well as colleague of Luce, wrote that the Archaic Burmese script found earliest on votive tablets "is cursive and the orthography archaic and uncertain." ${ }^{8}$ He continued that "these . . writings are good examples ... [that] illustrate the experimental stage in the gradual development of . . . writing a language before it is standardised." 9

In addition to the tautology-that Archaic Burmese showed archaism because it was archaic - the argument is fraught with other serious problems, not the least of which is that inconsistency of spelling alone is hardly a foolproof indicator of an inevitable, early stage in the development of a writing system, particularly Old Burmese. Even within Old Mon itself, Luce admits that "Rājakumār's spellings are much the same as his father's [Kyanzittha], but not quite so correct and careful. . . . This carelessness becomes increasingly conspicuous in the Mon inscriptions of the reign of the grandson (Alaungsithu) ..." [my emphasis $],{ }^{10}$ thereby demonstrating that as time passed, spelling did not necessarily become more consistent but sometimes even less. Shorto confirmed and extended this point by noting that the "extraordinary variations in spelling ... [were] at an extreme in classical Old Mon," 11 by which he meant Kyanzittha's Old Mon. ${ }^{12}$

In Old Burmese also, we regularly find inscriptions of Pagán after 1165 and the so-called "standardization" of Burmese (itself a problematic concept) continuing to display the "inconsistent" qualities of "prestandardization." 13 What I am saying is that "primitive" orthography does not always precede the mid-twelfth-century marker for standardization, nor does "advanced" orthography succeed it, since we often find stones with poor Burmese orthography inscribed after the ones with good (Queen's) Burmese. ${ }^{14}$ There are also many cases of inconsistent spelling in inscriptions that are contemporaneous to each other, and in some instances, inconsistencies within the same inscription.

To provide just one example, in the Nyaungyangyi Daughter's inscription of Sakarāj 604 (1242 AD), the penmanship ("stonemanship" if you 
will) and orthography is so beautifully precise and consistent that the scribe (or the stone mason whom she hired for the actual inscribing) must have had a standard set of metal punches-Pagán's equivalent to the typewriter, I suppose. All consonants, vowels, and medials are virtually the same size and shape (in length, width, girth, diameter, and height) throughout the inscription. ${ }^{15}$ So are the long-vowel markers of certain consonants, which suggests that the scribe must have had an additional set for making them.

Yet the texts of many later inscriptions showed much poorer penmanship as well as internal inconsistencies in orthography and calligraphy, suggesting not only that the scribe may have been inscribing "freehand," that is, without a complete set of standard punches, but was also less educated and hence the inconsistent orthography and sloppy calligraphy (and therefore, also less well paid for the work). This evidence calls attention to factors such as individual competence, education, training, technology, and economics, not simply linguistic or paleographic evolution.

Because scribes with different levels of education, penmanship, and literary competence were hired to inscribe stones, wide discrepancies in spelling can be found in both contemporary inscriptions and those distant in time. I suspect that scribes renowned for the quality of their work were also more expensive, and hence their clientele was limited to those who could afford them. As a consequence, the best Burmese can be found usually on those inscriptions issued by royalty or the elite classes. ${ }^{16}$ High-quality Burmese orthography was not necessarily the result of its advanced stage, or poorer-quality orthography, of its primitive stage, any more than "good" novels or compositions of today must succeed "poor" novels and compositions of yesterday.

It appears to me, therefore, that a more westernized conceptualization of the relationship between linear time and progress in human society was interjected into the analysis of the development of the Old Burmese script, so that what were really socioeconomic and technological circumstances had become "evidence" for a preconceived linear and progressive evolutionary scheme.

In the final analysis the flawed evolutionary scheme devised for written Burmese by the Mon Paradigm, did not, in any case, address the issue of whether the Old Mon writing system preceded that of Old Burmese because the evolutionary analysis was confined to Old Burmese. It did not compare it with Old Mon because Old Mon was already assumed to be earlier. To the best of my knowledge, not a single linguistic examination of the relative ages of these two writing systems-based on original, contemporary, and datable sources and independent of the Mon Paradigm's assumptions-has been published in English.

To be sure, Luce produced several comparative language charts, ${ }^{17}$ but 
they were based almost entirely on vocabulary and had little to say about the relative chronology of the writing systems except by inference. ${ }^{18}$ Similarly, Duroiselle's work in the Epigraphia Birmanica very ably demonstrated the probable way in which Old Burmese orthography developed, using the original words found on the Myazedi, but that process was confined to written Burmese only; it was not compared with written Old Mon, the issue at hand. In addition, the study was limited to the information found in the Myazedi Inscriptions and based on the assumption that the stones represent the first example of written Burmese.

Thus what has been offered until now is a contrived evolutionary sequence in which Old Mon was already determined to have preceded Archaic Burmese, Archaic Burmese (which was "characterized" by inconsistent spelling) was said to precede Standard Old Burmese (which was determined, erroneously, by consistent spelling). After that Standard Old Burmese "gained ground during the period of transition," another invented phase based on the above assumptions, until the reign of King Narapatisithu (1174-1211), "when Burmese became the main language of the inscriptions of Pagán." ${ }^{19}$ Although a historian, I cannot help but wonder what linguists would think of a scheme that used the orthography of one written language and its putative "evolution" as the ultimate (sometimes only) test for the comparative ages of the writing systems of two different languages?

\section{OLd Burmese in Domestic Lithic EPIGRAPHy}

What does the epigraphic evidence have to say regarding the Mon Paradigm's contention that the Burmese on the Myazedi Inscriptions was its earliest written example? ${ }^{20}$ The short answer is that not only is the Old Burmese on the Myazedi not the earliest evidence of written Old Burmese, but the evidence for written Old Burmese precedes that for written Old Mon in Burma by about a century. The sad truth is that most, if not all the evidence I use here was available to, ${ }^{21}$ and indeed largely compiled by, the second generation of the Mon Paradigm advocates. For various reasons, including the belief that it contradicted the Mon Paradigm, however, they did not consider this evidence viable.

Depending on how one counts, I have found to date approximately thirty-six Old Burmese ${ }^{22}$ inscriptions that precede the Myazedi, or thirtyseven, if one inscribed during the same year as the Myazedi is counted. ${ }^{23}$ Approximately twenty-four of them have been published in a volume containing forty-two inscriptions, arranged chronologically and carefully edited. ${ }^{24}$ Most of these are, however, recast stones ordered by King Bodawpaya in 1785 and now located in the Mahāmuni compound; they total approximately $719 .{ }^{25}$

The tradition of recasting old stone records was not new. Earlier kings 
had done what Bodawpaya did, having new stones cut of worn inscriptions, some now lost to us. The recasts summarize the contents of the originals; in most cases they include the donor's name, the day of the week and the year in which the original donation was made, and in a few cases duplicate the orthography of the original. Most important to the state and saingha in political and economic ways, the recast stones reaffirm the precise boundaries of the landed property that had been donated to the saingha. The main purpose of the recast stones was to verify the legal title to religious lands so that succeeding kings could, in the tradition of the kings named on the stones, redonate the lands as part of their own legitimation process. (It was also, of course, a way to keep track of the extent of tax-exempt sangha property. ${ }^{26}$

Although I look with some skepticism on the historicity of events mentioned on these recast stones, so far no Burma scholar has provided any good reason to question the existence of the originals they represent. At some point the originals from which these recasts were made did exist. In the case of King Bodawpaya's recasts, not only have most of the originals survived, but a comparison between the stones he copied and their originals show that although mistakes were made-such as the interjection of modernized spelling in some cases and the miscopying of some dates-in the opinion of Duroiselle himself, the "percentage of inscriptions of which the date has ... been misread is not on the whole very large...." ${ }^{27}$ Thus I use these twenty-four inscriptions here not for their information on historical events or orthography, but as representative of the general period in which their originals might have been written.

What is most important about these twenty-four stones is that eight of them belong to King Aniruddha's reign..$^{28}$ For a long time I wondered why there were so few inscriptions representing this most important reign for, apart from those in this group of twenty-four, there is only one surviving domestic original stone inscription attributed to Aniruddha, dated to 1058 AD. Yet Aniruddha was most likely the earliest, or at least one of the most effective consolidators of the Pagán kingdom. He was said to have been responsible for many of the technological and military achievements that allowed the expansion of the state and was probably the one who vigorously initiated, on a statewide level, the patronage of the saingha as a legitimating ideology of the state-the public expression of which are these very same donative stone inscriptions. Considering this, the extent of his patronage expressed on stone should have equaled if not surpassed that of many of his successors, and indeed that is how it is recorded in the chronicles. ${ }^{29}$ Even the number of temples attributed to Aniruddha-each of which would ordinarily have had a stone record-far exceeds the number of inscriptions found during his reign if we discount these recast inscriptions. ${ }^{30}$

The scope and scale of temple construction by the king prior to any 
invasion of Lower Burma has convincing support from data analyzed by archaeologist Bob Hudson. ${ }^{31}$ In his study, based on Pierre Pichard's Inventory of Monuments at Pagán, of eighty-six dated temples and monasteries constructed at Pagán, Hudson calculated the total volume (in cubic meters) of bricks, mortar, stone, and dirt used to build these edifices during the period 1050-1399 and then graphed this activity chronologically, with the dates divided into approximately ten-year segments. His work confirms an earlier study of mine, which used epigraphy only, that examined the amount of land, labor, and money that flowed to the saigh a from state and society. His graph more precisely confirms my study regarding the general pattern, scale, scope, and chronology of temple-building in Pagán. Hudson's data show two large construction peaks beginning in $1050 \mathrm{AD}$, before the alleged conquest of Thatôn in 1057 and the alleged importation of Mon artisans and craftsmen, said to have been crucial to the temple-building program in Pagán. My study shows a similar, though less dramatic, development during the same time. ${ }^{32}$

This obvious development in temple-building during Aniruddha's reign is not consistent with the number of donative inscriptions conventionally attributed to his reign and earlier. Thus, although many of these recast inscriptions fill an important gap in the information about the Aniruddha period, as well as the chronology of religious donations made during it, they and the period they represent have been ignored or dismissed because they do not support the thesis that Old Mon precedes Old Burmese. Since these recast stones were inadmissible as evidence, the role of Old Burmese writing during Aniruddha's reign has also been dismissed. That, in turn, allowed the exaggeration of the role and period of his most notable successor, King Kyanzittha, who wrote mainly in Mon.

The dates on these twenty-four inscriptions all precede the Myazedi Inscriptions, in one case by over a century. This last date is recorded as Sakarāj 346 or 984 AD, ${ }^{33}$ although a few internal contradictions cast some doubt on its reliability. ${ }^{34}$ But the point I am trying to make is that it most likely had an original, dated to 984, well within the early decades of the Pagán Dynasty. This is when Saw Rahan (956-1001) and Kyaung Phyu Min (1001-1021), Aniruddha's grandfather and father, reigned, both of whom have been corroborated independently. ${ }^{35}$ And as stated in an earlier chapter, new radiocarbon dates show that as early as $650 \mathrm{AD}$ there was urban settlement at Pagán, while the foundations of the walls date to between 990 and $1030 \mathrm{AD}$. Also important, among the twenty-four recast inscriptions, eleven belong to the reigns of Aniruddha's two successors, Saw Lu and Kyanzittha, so they all predate the Myazedi. ${ }^{36}$ Even if we discount the 984 AD stone, there is still ample evidence that Old Burmese was being written prior to the Myazedi Inscriptions of 1111/1112-1113. 
However, lest these 24 stones be considered inadmissible as evidence for being recasts and not originals-which is after all my own criterion throughout this book for determining reliability-there is another, more recent compilation of inscriptions called She Haung Myanma Kyauksa Mya [Ancient Burmese stone inscriptions], volume I, which contains 225 original Old Burmese inscriptions dated from Sakkarāj 474 to 600, that is, 1112 to $1238 \mathrm{AD}$. (Note the starting date of the volume, 1112, the date for the Myazedi; so even the organization of a volume of inscriptions published in 1970 had assumed the Mon Paradigm to be correct.) Partly for that reason, volume I is divided into two sections, A and B (in Burmese $k a$ and $k h a$ ). Section A includes 187 Old Burmese inscriptions considered originals and presumably struck around the same time as the events they describe; section B contains 38 Old Burmese inscriptions considered less reliable, although nearly all still belong to the Pagán period. Some have been placed in the B section for reasons having more to do with the fact that they contradict assumptions of the Mon Paradigm than their intrinsic value. Of the 38 original Old Burmese inscriptions in section $\mathrm{B}$ that are dated, 7 precede the Myazedi. ${ }^{37}$

There is another original Old Burmese inscription that was not included in the She Haung Myanma that also precedes the Myazedi. It is found in a compilation called Pagán Kyauksa Let Ywe Sin ${ }^{38}$ [Selected inscriptions of Pagán] by E Maung. The stone is apparently dated to 1082 AD, although I am not entirely clear how the editor arrived at that conclusion. ${ }^{39}$ In a third compilation, this one by Luce and Pe Maung Tin, titled Selections From the Inscriptions of Pagán, that includes only what they considered to be originals, there are four Old Burmese inscriptions that predate the Myazedi stones ${ }^{40}$ three of which have already been included in the She Haung volume, thus adding a total of one more original Old Burmese inscription that preceded the Myazedi. In short, the Myazedi Inscriptions do not represent the earliest evidence of written Burmese. There are either eight or nine (if E Maung's 1082 inscription is counted) original Old Burmese inscriptions that precede the Myazedi excluding the twenty-four Bodawphaya recasts.

\section{Old Burmese at the Mahābodhi Temple}

In addition, two Old Burmese inscriptions were found at Bodhgayā at the Mahābodhi temple in the early part of the nineteenth century. They had been left there by envoys from at least three different missions sent from the kingdom of Pagán. The first left an Old Burmese inscription on a copper-gilt umbrella discovered eight feet under the modern ground level. It includes a line of text in Old Burmese under which is another line in 
what Sir Alexander Cunningham, noted India epigraphist and archaeologist, called mediaeval Nāgarī.

Although the first, most important digit on this Old Burmese text is not very clear and much damaged, the date given by the Nāgarì text is clear and reads "Sam 397." Cunningham assumes the Burmese used the Cūlasakarāj dating system and wrote that the damaged numeral "ought to correspond with that in the Indian inscription below," and therefore dated it to 1035 AD. ${ }^{41}$ The "Sam" preceding the numeric date is a bit puzzling, but it may be a misreading for "Sak," the abbreviation for Sakarāj, the era used in virtually all inscriptions of Pagán. ${ }^{42}$

As Cunningham was unable to read the entire date on the Burmese text because the copper has been crushed where the first digit was inscribed, he provided both a photograph of the copper text and a conjectural hand copy of it in his published work. But since the first digit on the copper is illegible, the hand copy had to be conjectural also, and that is what Luce stated he read. From that conjectural hand copy, he interpreted the date as Saka$r \bar{a} j$ [6] 55, or 1293-1294 AD, placing the event in the thirteenth rather than the eleventh century. Luce made no comment on the Nāgari text, the date of which was legible and confirmed Cunningham's conjectural reading of the Burmese date to 1035 AD. ${ }^{43}$

Unfortunately, even the two legible numerals of the date on the copper shown in the photograph provided by Cunningham are not accurately represented by the hand copy. On the hand copy, the two numerals do indeed look the way Pagán epigraphists would write "55," and therefore probably misled Luce into reading them as [6]55. On the photograph, however, they do not look like 55, but rather like 97 . Nevertheless, misreading the last two numerals as 55 still does not justify reading the first illegible digit as a 6 , especially when the Nāgari text is clearly 3 .

Cunningham's reading of the Nägari date as 397 would place the first Bodhgayā mission in the reign of one of Aniruddha's predecessors, Kyi-zo, whose historicity is confirmed by the most reliable and earliest of Burmese chronicles, the Zatatawpon. ${ }^{44}$ More pertinent to the present topic, it demonstrates that written Old Burmese preceded the alleged conquest of Thatôn in 1057 by twenty-two years, the first dated Old Mon inscription in Burma (Kyanzittha's 1093 stone) by fifty-eight years, and the Myazedi Inscriptions of 1111/1112-1113 by more than seventy-seven years.

The second Old Burmese inscription at the Mahābodhi temple is more informative, and ultimately more important, for it has two legible, more precise dates on it and represents the last two missions. The stone was said to have been discovered in 1833 by Capt. George Burney, brother of Col. Henry Burney, British Resident at Ava and Amarapura, when the former 
was on a visit to Bodhgayā. ${ }^{45}$ The narrative provided by this inscription describes the various dedications and repairs that had been made to the temple at different times, beginning with King Aśoka, who built the original temple. Subsequently, repairs were made by one Pańsakū krī, a senior monk, after which additional repairs were said to have been made by a Siri Dharma Rājakuru (or Guna, depending on the reading), and finally repairs were made by the last two missions, at the completion of which this stone inscription was dated and erected. ${ }^{46}$

Cunningham's reading of the Nägari on the copper-gilt umbrella confirms at least the title "Sri Dharma Raja Guna" that is attached to an individual mentioned on both the umbrella and the inscription. Although Cunningham stated that he could not make out the rest of the Burmese on the umbrella, my reading of both the photograph and hand copy is "Sri Dharma Raja Guna Paṅsakū krī." 47 To me it appears as a single title (combining the Raja Guna and the Pańsakū krī), not two different ones. ${ }^{48}$ Whatever the case may be, the information given on the stone inscription not only confirms there was indeed an earlier, first mission, but also corroborates the title or part of a title of an individual involved in that mission, thereby lending much credibility to Cunningham's reading of the Nägari date as $1035 \mathrm{AD}$ and not Luce's that places it in the thirteenth century.

Copies of the stone inscription were sent to Col. Henry Burney, who along with Burmese scholars at Ava read its dates as Sakaräj 467 and 468 (1105 and 1106 AD respectively). In 1862 Cunningham also saw the inscription, "fixed in a wall" he wrote, at the residency of the Mahant (a religious official). Cunningham's reading of the Burmese dates on it was Sakarāj 441 and 448 (AD 1079 and 1086 respectively). This agrees with the reading by Burney and the Ava scholars in terms of the centenary numbers but differs on the decade and one of the years. Three other scholars also tried their hand at reading these dates ${ }^{49}$ and came to the conclusion that the first digit represents a 6 rather than a 4, thereby placing the missions in the thirteenth century. One last attempt to read the dates prior to this writing was made by Luce, who in 1976, not surprisingly, read the dates as 657 and 660, which also placed the second and third missions in the thirteen century, and coincided with his reading of the illegible first digit on the umbrella as a 6 . In that 1976 article, Luce lamented the "failure of Ava scholars to read correctly" those dates, which "threw them [and also Cunningham] two centuries out in their reckoning." ${ }_{50}$ But, as we shall see, it was Luce whose reckoning was wrong.

I have also read the microfilm ${ }^{51}$ of the rubbing of the stone inscription and concur with Cunningham and Burney that the centenary date should be a 4, although the decades and years are not entirely clear. The most important factor in this controversy is, however, not the decade or year, impor- 
tant though they may be, but the century. At present, the issue ultimately boils down to interpretation: whether the first digit was a 6 or a 4, and, therefore, whether the missions occurred in the thirteenth or the eleventh centuries.

Fortunately, and even if the year is a matter of interpretation, the names of the week and month days were included in the stone inscription, and their readings are not contested. The first is recorded as Friday the 10th day of Pyatho (December/January), and the second as Sunday, the 8th day of Tazaungmôn (October/November). Realizing the importance of these details, Cunningham tested all conjectured years with the respective week and month days. He concluded that none matched any of the conjectured thirteenth-century years, but corresponded with the years Sakarāj 441 and 448 (1079 and 1086 AD). ${ }^{52}$

Since Cunningham's work preceded Luce's by almost a century, he obviously did not include Luce's readings in his tests. So I had Luce's dates cross-checked with J. C. Eade's invaluable reference work, Southeast Asian Ephemeris, with the indispensable help of my colleague Ken Breazeale from the University of Hawai'i's East-West Center who understands Eade's underlying mathematical principles and their tables which I do not. ${ }^{53}$ It turns out that Cunningham was right. The week and month days in Sakarāj 657 and 660 (Luce's years) do not correspond with those on the Mahābodhi Inscription. Friday, the 10th waxing day of Pyatho in Sakarāj 657 AD falls on a Saturday, not a Friday, while Sunday, the 8th waxing of Tazaungmôn in Sakarāj 660 falls on a Tuesday, not a Sunday. I also had Cunningham's dates of Sakarāj 441 and 448 retested with Eade's work, and they are virtually right on the mark. ${ }^{54}$

There are, of course, a multitude of factors to consider when determining these dates, such as intercalary months, leap years, and things affecting the calculation of days of the week, and so on. But Eade's formulas take these factors into consideration, and even though his system is based on mathematical probability, those who have used it for the past decade have found it to be very accurate. ${ }^{55}$ The only unknown that needs to be calculated here, in any case, is whether the years chosen by the different scholars corresponded with the week and month days already given by the Mahābodhi Inscription. In other words the known week and month days are the basis for calculating the unknown, conjectured years; there is no need to alter the week or month days, unless, of course, they do not correspond with one's preferred years.

This explains why the AD equivalents that Luce gave for his chosen years 657 and 660 were at first puzzling. As noted above, when Friday the 10th waxing of Pyatho is calculated according to Eade's tables using Luce's year 657, it falls on Saturday, December 17 th. Yet Luce gave an AD equiva- 
lent of Friday, December 16 th, ${ }^{56}$ which is not the 10 th, but the 9 th waxing of Pyatho. Thus he appears to have deliberately chosen the wrong day of the month in order to get the correct day of the week (Friday), as given in the inscription. That this was not merely accidental is revealed by his doing the same thing with the second date. When Sunday, the 8th waxing of Tazaungmôn given on the inscription is calculated according to Eade's tables using Luce's year 660, it falls on Tuesday the 14th of October, not, as Luce has it, on Sunday the 12 th of October..$^{57}$

What Luce seems to have done in both cases was to make sure that the days of the week given on the Mahābodhi Inscription were matched by a Friday and Sunday during Pyatho and Tazaungmôn of his years 657 and 660 . This implies that he had to have had in front of him a relevant Burmese calendar or had to have calculated the dates using known formulae, for it is not the kind of information that one carries in one's head. That Luce was familiar with the calendrical system and its implications is shown in volume III of his Old Burma, pages 327-337.58 That means Luce must have been aware that Cunningham's years were virtually on the mark (and his own were not), for Cunningham's years would have shown up in his calculation process or in the tables he consulted. Of course it is also possible that Luce did not want to check Cunningham's dates. Therefore, despite chiding Burney, the Ava scholars, and Cunningham, it was Luce who was two centuries off in his reckoning. At least Cunningham, Burney, and the Ava scholars were intellectually honest and did not deliberately substitute bogus days to match those found on the inscription.

This calendrical evidence makes it fairly certain that all three missions occurred in the eleventh rather than the thirteenth century. That in turn means that the first mission which produced the copper-gilt umbrella dated to 1035 was indeed sent during King Kyi-zo's reign, while the missions of 1079 and 1086 occurred during King Saw Lu's and Kyanzittha's reigns respectively.

The evidence that these three missions occurred in the eleventh century needs no further corroboration, yet the case would certainly be enhanced if additional evidence was found, particularly if it was contemporary to the period of the missions. Fortunately-and this sort of corroboration rarely occurs-there are two inscriptions of the eleventh century that confirm one, and perhaps both missions, and in one case in terms of the exact date as well.

The first is an Old Burmese inscription, part of which dates to 1086 and part to 1105 . It was erected by one "Matima Mahāthera" who, the context suggests, may have been the primate of at least two kings, Saw Lu and Kyanzittha, not entirely an uncommon practice in Burmese history. ${ }^{59} \mathrm{He}$ states explicitly that he went to worship at the Mahābodhi in Sakarāj 448 
(1086 AD), the same date given by the Mahābodhi Inscription of the second mission, which also records that the primate of the Burmese king had come to Bodhgayā to oversee the Mahābodhi's restoration. ${ }^{60}$

But there might be a problem with the Mahāthera's statement, for it appears to suggest that his journey occurred around the time or shortly after King Aniruddha's successful campaign in Lower Burma, although Aniruddha's reign ended about a decade before 1086. At the same time, however, this discrepancy may be a misreading on our part, for there are four different readings of it. ${ }^{61}$ In any case, the section regarding the date of the Mahāthera's trip to the Mahābodhi temple itself, 1086, is unambiguous, and it corresponds with Cunningham's reading of the second date on the Mahābodhi stone inscription.

The Mahāthera continues his narrative, stating that during Htilaing Shin's (Kyanzittha's) reign, in Sakarāj 467 (1105 AD), he donated some lands (in Burma). ${ }^{62}$ As the 1105 portion of the stone follows the 1086 section rather smoothly, the Mahāthera may have inscribed the entire narrative in $1105 \mathrm{AD}$, and referred back to 1086, when he took the trip to Bodhgayā. But he could also have simply added the 1105 portion later to the original 1086 portion. Either way, it appears that the Mahāthera was a contemporary of Saw Lu and Kyanzittha, and perhaps even of Aniruddha.

Yet the Mahāthera's record-clearly a contemporary inscription and therefore the best evidence one is going to find to corroborate the Bodhgayā mission sent from the kingdom of Pagán-was relegated to the "B" section of the She Haung because, among other reasons, it contradicted the Mon Paradigm claim that the first evidence of written Old Burmese cannot precede the Myazedi Inscriptions.

The second source that corroborates the second mission is the Old Mon inscription of 1093 erected by King Kyanzittha at Prome. It states:

Thereafter . . . the holy temple of Śrī Bajrās [the Mahābodhi] . . . (which had been) destroyed, ... King [Kyanzittha] got (together) jewels of divers kinds (and) sent (them in) a ship with intent to build up the holy (temple) of Śrī Bajrās, to buy (land?) . . . (to dig a tank?) . . . to irrigate (?) arable land, to make dams, in order to burn tapers that should never be allowed to go out, to present drums, . . . xylophones, singing (and) dancing. . . . Thereafter, the great buildings which King Dharmāsok [Aśoka] built, which (were) old (and) in ruins, King [Kyanzittha] proceeded to build anew, (making them) finer than before. . . . ${ }^{63}$

We should note the emphasis on the funds that were acquired for the restoration of the Mahābodhi temple, for this is also recorded in the Mahābodhi Inscription as the expressed purpose of the second mission. In addi- 
tion to the usual gold and silver offerings, the Mahābodhi Inscription notes the buying of land and cattle and the dedication of people to maintain the temple ${ }^{64}$ descriptions explicit or implied in the Prome Inscription.

The similarity of information in both the Mahābodhi and Prome inscriptions suggests that they were referring to the same mission. And since the Prome Inscription is dated to and erected in $1093 \mathrm{AD},{ }^{65}$ it is in a position to reaffirm both the first (1035) and second (1079 and 1086) Mahābodhi missions. Had the missions occurred in the thirteenth century, as Luce contended, how could this 1093 inscription know about them? All this, prima facie, verifies that the Old Burmese on the Mahābodhi preceded the first dated Old Mon inscription of Burma (1093) and that the missions took place in the eleventh and not the thirteenth century. Other missions were doubtless sent to Bodhgayā after the eleventh century; indeed, they remained a regular feature of the Burmese state well into the modern period. But as far as I know there are no thirteenth-century inscriptions in Burma that corroborate the information found on the Mahābodhi Inscription as explicitly as the two inscriptions just discussed do.

Luce's response to the above evidence (and he must have been thinking about it) was in the following manner. He rather arbitrarily divided the Old Prome Inscription of 1093 into two parts. The first part he acknowledged referred to a mission to Bodh Gaya, India, but does not offer any explanation for his own thirteenth-century readings of the Bodhgayā Inscriptions. ${ }^{66}$ The second part, beginning with "Thereafter, the great buildings which King Dharmāsok built, which (were) old (and) in ruins, King [Kyanzittha] proceeded to build anew, (making them) finer than before, ... ." Luce argued, referred to "the cetī of Kyāk Talan்" and "the prāsāda of the great relic of Satih," near Mt. Kelāsa north of Thatôn, . . ." not to Bodhgayā and the Mahābodhi temple. ${ }^{67}$

But nothing in the inscription even hints that the narrative of the mission had suddenly shifted from India to Lower Burma. The inscription states clearly that King Aśoka built these temples in India, not Burma, for which Luce had another answer, that this Dharmāsok was really an early Mon king of Thatôn, not Aśoka (thereby additionally "confirming" Thatôn's early existence).

The facts are that two independent sources, both contemporary to the events described in the Mahābodhi Inscription of Bodhgayā, not only corroborate precisely some of the narrative found in the Old Mon inscription of Prome, but confirm that the missions occurred in the eleventh century (and, therefore, that Old Burmese was being written at that time even in a foreign land). This is the kind of corroboration one can only pray for, particularly when dealing with stone epigraphs of a millennium ago. Yet their 
importance was ignored for a century and disingenuously deconstructed because it did not support a favorite thesis.

Of the Old Burmese inscriptions recovered in India, then, the 1035 copper-gilt umbrella inscription precedes the Myazedi Inscriptions by seventy-seven years and the alleged conquest of Thatôn by more than twenty-years. Indeed, it preceded King Aniruddha himself by about a decade. The first date on the second Mahābodhi Inscription (1079) demonstrates that written Old Burmese preceded the Myazedi Inscriptions by thirty-three years and the second date (1086) by twenty-six years. In short, the evidence shows that the first instance of written Old Burmese not only precedes that found on the Myazedi but also the first dated evidence of written Old Mon in Burma, effectively removing a major foundation stone of the Mon Paradigm.

\section{Old BuRmese in Votive Tablets}

Original domestic lithic epigraphy in situ is perhaps the most informative and reliable in revealing the place of written Old Burmese in the history of Pagán and Burma. Such objects are heavy, cumbersome, essentially permanent legal records, not easily or meant to be moved. They inform us of provenance and most accurately represent the social and political context in which they are found.

In contrast, the votive tablet, which is easily carried in a bag, is not meant to be a fixed, dated, legal, or permanent record. It is therefore not as reliable in revealing either the context from which it was derived or its chronology, and its provenance is usually even more obscure. However, when the information on votive tablets reinforces that found on stone records, then their importance as a source appreciates. The evidence extracted from these votive tablets, therefore, should be seen as supplementary to the stone data, not the main source of information.

Hundreds ("thousands" according to Duroiselle) of votive tablets written in Old Burmese have been discovered. ${ }^{68}$ Unfortunately, although none of these tablets is dated precisely, all Burma scholars knowledgeable about the subject attribute most of them to Aniruddha's reign-hence they are called "Aniruddha style votive tablets"-based mainly on paleography and style. If that stylistic and palaeographic assessment is correct, it once again places the writing on them to a period well before both the Myazedi Inscriptions and the first evidence of written Old Mon in Burma.

Of course, those subscribing to the Mon Paradigm could not allow this analytical concession, as we can see in this example from Ba Shin. He was studying the Lokahteikpan temple and attempting to date it by comparing ink inscriptions found on its walls with the script found on these votive 
tablets. He noticed that the ink inscriptions in Burmese were similar to the writing on the votive tablets, which he said represented some of the "oldest specimens of the Burmese written language extant. They record the names of trees, fruits, flowers, vegitables [sic], herbs, etc. offered to the Buddha." ${ }^{69}$ But if we use Ba Shin's own chart and compare the written Burmese on the votive tablets and the ink inscriptions in the Lokahteikpan temple with the writing on the Myazedi Inscriptions and other Old Burmese samples from later periods, it is clear that the written Burmese on the votive tablets shows a remarkable dissimilarity, and far less congruence between it and all the rest, including the writing found on the Lokahteikpan and the Myazedi. ${ }^{70}$

For example, of the approximately thirty-eight words taken from the votive tablets, not a single one was similar to any word on the Myazedi in meaning or orthography. Comparing the words on the Lokahteikpan temple with those on the Myazedi produced only five words out of fifty-four that are similar in meaning and spelling. In other words, Ba Shin's own evidence does not support his contention that the Burmese on the temple or on the votive tablets was similar to that on the Myazedi.

Ordinarily that incongruity would have immediately suggested to someone not influenced by the Mon Paradigm that the writing on the votive tablets, as well as that in the Lokahteikpan, were possibly older than the writing on the Myazedi, particularly since most scholars familiar with the votive tablets place them in Aniruddha's reign, which preceded the Myazedi by over sixty-five years. But since Ba Shin, following Luce, had already stated that the Myazedi was the oldest dated Burmese inscription, ${ }^{71}$ he was compelled to date the writing on the Lokahteikpan to a period close to the Myazedi; ${ }^{72}$ indeed, he had to select a later date if he did not want to dislodge the entire Mon Paradigm. He therefore assigned the date of the temple itself, which does not have one, to a period after the Myazedi so that, in a circular fashion, the evidence in it of what he called "pre-Standard" Burmese automatically succeeded the earliest dated Mon inscription of 1093. And because, by association, he considered the Burmese writing on the votive tablets to be "pre-Standard" Burmese, the Burmese script on them was also placed later than the writing on the Myazedi.

Yet since his own comparative language chart showed a marked dissimilarity between the votive tablets and the writing on this temple with that on the Myazedi, he should have immediately noticed that something was amiss between his analysis and his evidence. But because Ba Shin was operating under the assumptions of the Mon Paradigm that the oldest written Burmese was represented by the Myazedi, the only conclusion he could have reasonably reached under the intellectual shackles he was in, was to date the Archaic Burmese in the Lokahteikpan and on the votive tablets to correspond with the Myazedi, rather than earlier, despite his data that 
showed otherwise. Had he not been under the theoretical constraints of the Mon Paradigm, I wonder where he would have placed the Burmese of the Lokahteikpan and the votive tablets? The latter never got a chance to be examined independently of the Mon Paradigm. ${ }^{73}$

"Aniruddha style" votive tablets were found all over the country, including at Pagán, Prome, Tagaung, Minbu, Sagaing, Arakan, Bassein, Thatôn, Tavoy, Pegu, Twanté (near Yangôn), and Mergui, on the tip of the Tenasserim Peninsular; in short, they cover the extent of the kingdom. Some even found their way to Bodhgayā and the Mahābodhi temple as we have seen. ${ }^{74}$ Of the domestic votive tablets uncovered so far, approximately 108 were selected for their condition and typology, and described and analyzed by $\mathrm{U}$ Mya in $1961 . .^{75}$ In 1969, in his Old Burma-Early Pagán, Luce also dealt with the subject, using a somewhat different typology. ${ }^{76}$

Many are recorded in Pali and Sanskrit, usually written in medieval $N \overline{a g a r i}$ and proto-Bengali script of the period between the ninth to the thirteenth centuries. ${ }^{77}$ Most discovered so far, however, are written in "Archaic" Burmese, and a hoard of nearly a thousand was found at Pagán. ${ }^{78}$ Of those that use the Mon language written in the then-current Pagán script, ${ }^{79}$ we can count approximately thirty-one among the group chosen by Luce, ${ }^{80} \mathrm{a}$ far cry from the thousands found written in Old Burmese.

The function of votive tablets during Pagán times varied. They served as religious souvenirs for pilgrims visiting the capital, so that one scholar likened them to the postcards of today. ${ }^{81}$ They also record donations made by commoners who could not afford to build expensive monuments such as stupas and monasteries. They were placed in edifices built by someone else at the time of consecration in order to accrue part of the merit that derived from the builder's donation. There must have also been other religious and secular functions of which we are not aware.

However, votive tablets made by or belonging to kings and officials of state, such as those issued and signed by Aniruddha himself, can be regarded as markers of a different sort. Since Aniruddha was not picking up souvenirs to show off to his friends that he had been to Pagán, his tablets were statements of his political influence and perhaps even control in the areas where they were found. Prince Saw Lu, probably Aniruddha's designated heir, was said to have issued at least one such votive tablet found at Mergui. ${ }^{82}$ Two other "official" votive tablets, written in the Mon language, were also found near Tavoy. They belonged to two governors who had been appointed by King Kyanzittha to administer the province. Luce writes that the Mon on them is "of Kyanzittha's reign." ${ }^{83}$

On the one hand, then, we should not depend on votive tablets, particularly "commoner" ones, to give us precise, quantitative information regarding the ethnolinguistic makeup of the region in which they were 
found, simply from the languages found on them. To suggest that there may have been a sizeable population of those who spoke the same language as that found on the votive tablets could be just as misleading as to conclude, in today's world, that if one finds many Chicago Bulls T-shirts being worn in Bangkok, the lingua franca must have been English.

On the other hand, we can infer that the proportion of tablets containing a certain language, when compared to the total number of tablets found, provides a clue as to the relative size of the population that spoke that language visà-vis other languages. Because the Burmese language is represented by the largest number of records found during the Pagán Dynasty as a wholewell over 90 percent if one includes stone inscriptions-it is not unreasonable to assume that most of the population at the time the writing was produced and in the place where these records were found must have been Burmese speakers. This is especially true of the tablets inscribed by commoners, since royal languages can sometimes be minority languages, as is evident in Kyanzittha's case.

Perhaps more interesting, the large number of commoner votive tablets suggests that ordinary people, or those they paid to do so, were writing in Old Burmese as early as Aniruddha's reign, an unlikely situation had Aniruddha first obtained the script only in 1057. It further provides evidence regarding one of the known functions of the saigha throughout Burma's history, that is, the education of the general populace. That it performed a function during the Pagán period similar to what it has done in modern times is confirmed by other contemporary epigraphs. ${ }^{84}$ Literacy among the general population is not something achieved in a few years, perhaps not even in a few decades, so that ordinary folk probably had knowledge of written Burmese well prior to 1057, conceivably well before Aniruddha's reign. ${ }^{85}$

In the final analysis, because the beginning of Aniruddha's reign precedes the beginning of Kyanzittha's by about forty years, the votive tablets made during Aniruddha's reign with Old Burmese written on them, even if undated and regardless of who wrote them, would still be earlier than the earliest Old Mon inscriptions of Burma first found during King Kyanzittha's reign, and would be over half a century earlier than the Myazedi Inscriptions. Not only do these votive tablets demonstrate that Old Burmese preceded Old Mon writing in Burma, but they also give additional credence to the presence of written Burmese on the original stones from which Bodawpaya had recast the twenty-four inscriptions discussed above, especially the one dated to $984 \mathrm{AD}$.

In summary, and contrary to the Mon Paradigm claim, written Old Burmese in lithic inscriptions and votive tablets was present in Pagán (and in India) well before the alleged conquest of Thatôn in 1057, before the 
first securely dated Old Mon inscription erected in Prome in 1093, ${ }^{86}$ and before the Myazedi Inscriptions of Pagán in 1112-1113. It even precedes the Old Mon inscription of the Shwézigôn Pagoda Inscription, conjecturally assigned to 1086, a topic discussed in the following section.

\section{The Place of Written Old Mon in Burma}

As noted, the first dated Old Mon inscription to be erected in Burma was at Prome in 1093. The second oldest dated Old Mon inscription found so far appears five years later at Thatôn in the form of two, perhaps three duplicates, also products of King Kyanzittha. The rest of his Old Mon inscriptions are either undated or assigned dates by inference, not surprisingly, to fit the Myazedi declaration and therefore the Mon Paradigm. The most problematic among these is the Shwézigôn Pagoda Inscription, thought to be Kyanzittha's, and assigned by Luce to $1086 \mathrm{AD},{ }^{87}$ thus pushing the chronology of written Old Mon in Burma to over a decade before the securely dated 1093 Inscription.

There are serious problems with this conjecture. First, the inscription itself has only the following to say about its own date. Speaking in the Buddha's voice, it states: "A thousand six hundred (and) thirty years from my achievement of Nirvāna, at that time shall he [presumably Kyanzittha] become king of the Law in the city of Arimaddanpūr." ${ }^{8}$ Nothing is said of when the Shwézigôn Pagoda itself was built or the date when the stone itself was erected, although the temple has generally been attributed to King Aniruddha much earlier. The inscription mentions only the year of King Kyanzittha's probable accession to the throne, which, if reckoned according to the Burmese tradition of the parinibbānna (544 BC), means this king named Śrī Tribhuvanāditya Dhammarāja shall be king of Pagán in 1086 AD. Only if one assumes that this accession occurred on the same date as the building of the Shwézigôn Pagoda-there is no such hint in the inscription itself-might $1086 \mathrm{AD}$ be considered the date of the earliest Old Mon inscription in Burma.

Even granting that, written Old Burmese still precedes this inscription, for the original Jātaka plaques on the Shwéhsandaw temple, which belong to Aniruddha's reign, are written in Pagán Old Burmese, ${ }^{89}$ and his reign precedes Kyanzittha's by approximately forty-two years. These plaques, then, are still earlier than the date given to the Shwézigôn Pagoda Inscription. Moreover, the Jātaka plaques found on the two Hpetleik temples (to be discussed in Chapter Nine), and written in Pali in the Pagán script, also date to before and during Aniruddha's reign. ${ }^{90}$ In addition, four other dated Old Burmese inscriptions precede the date to which the Shwézigôn Pagoda Inscription has been assigned: one in 1058 (nearly thirty years ear- 
lier), one in 1081, two in 1082, and a fifth is contemporaneous with it, in $1086 .^{91}$

Apart from these, the copper-gilt umbrella inscription of the Mahābodhi temple (1035) predates the Shwézigôn Pagoda Inscriptions by over three decades and precedes the first dated Old Mon inscription at the Prome Shwéhsandaw by fourteen years (and those of Thatôn in 1098 by nineteen years). The mission dated to 1079 on the second inscription of the Mahābodhi would fall ten years earlier than the conjectured date for the Shwézigôn, while the second mission (1086) would be contemporary with it.

And if the recast inscription dated to 984 is permitted as evidenceonly for indicating the probable presence of its original and nothing moreit suggests that Old Burmese writing could have preceded both the Old Mon Shwézigôn Inscription assigned to 1086 and the securely dated Prome Inscription of 1093, the first by nearly a century and the second by more than a century. The 984 date also precedes Aniruddha himself, and his alleged conquest of Thatôn by seventy-three years.

After the Shwézigôn, Prome, and Thatôn Inscriptions, the Old Mon script appears on Kyanzittha's new palace inscription, assigned to 1102 AD, and the Jātaka plaques on the Ānanda temple, assigned to 1105 . But once again, these are given dates designed to bolster the Mon Paradigm. In any case, they do not precede the Old Burmese inscriptions already discussed. Thereafter, Old Mon appears on the Myazedi Inscriptions of 1112-1113, by which time written Old Burmese had been around for decades, perhaps nearly a century. Finally, written Old Mon in the Pagán script can be found in numerous but undated ink inscriptions inside several temples, and appears at Haripuñjaya subsequently.

Not only does the earliest Old Mon writing in Burma not precede Old Burmese writing; it is also relatively late. This late appearance is supported by Mon scholar Gerard Diffloth who writes: "In the Mon heartland of Lower Burma, it is not until the XIth century, with one possible exception, that Old Mon inscriptions begin to appear. . .." ${ }^{92}$ And that one exception, Diffloth noted, is a tablet shown to him by Nai Pan Hla which was said to have been found at Winga in Lower Burma, a site assumed to have been prePagán Mon. But the tablet is not dated; nor has it been shown to have been unearthed in a scientific excavation process that stratigraphically placed it in a pre-Pagán level. So its provenance and chronology are unclear and unknown. In fact, there is some question as to the date of Winga itself, since the most recent thermoluminescence analysis of two Winga shards date to the very late fifteenth and the seventeenth centuries, which were actually, not coincidentally, the glory days of the later Mon Kingdom of Pegu.

The lateness of Kyanzittha's Old Mon inscriptions, as compared to writ- 
ten Old Burmese, partly explains why Kyanzittha's inscriptions also show such high literary quality from the outset ${ }^{93}$ While there is no evidence that the Old Mon script of Pagán had gone through an earlier stage of development in Lower Burma, as one would expect if it had come from there, we can see such a sequence in Old Burmese. ${ }^{94}$ By the time the Pagán script was used for writing the Old Mon language in Burma, the script was already a well-developed, polished eleventh-century product, ${ }^{95}$ having gone through several centuries of evolution in Old Burmese.

To summarize, there are, in all, approximately thirty-six Old Burmese lithic inscriptions that precede the Myazedi Inscriptions, fifteen of which are original. About eleven are contemporary to the events they describe, while twenty-four are recasts. Of the total, approximately twenty-six Old Burmese inscriptions precede the first dated Old Mon inscription of Burma, twenty-seven if another erected on that same date is counted. Even if the twenty-four recast inscriptions of King Bodawpaya are inadmissible as evidence because they are not originals, only a single original contemporary inscription with a legible date is needed to prove that Old Burmese writing preceded both that found on the Myazedi and the earliest written Old Mon inscription in Burma. Among the corpus discussed, there are at least thirteen that meet the first requirement, and approximately six, the second. Written Old Mon, therefore, was preceded by written Old Burmese in the country, and moved from the Dry Zone, where the Pagán script originated, to Lower Burma and from there to Haripuñjaya in northern Thailand. It did not go the other way around as has been believed.

\section{Conclusion}

For over a century, written Old Mon was thought to have preceded written Old Burmese. That, in turn, has shaped the interpretation of Pagán (and Burma's) history in no small way. Yet, all analyses have been based on the same assumption with which the Mon Paradigm began: that for a millennium prior to the rise of Pagán there existed in Lower Burma a Mon civilization called Rāmaññadesa whose capital was Thatôn and whose culture (which included the Burma script) was transported to Pagán by the conquest of Aniruddha in 1057. This all-encompassing theme has been so thoroughly enmeshed in the historiography of early Burma that its extraction from the evidence has meant excising countless layers of historiography that most scholars have come to accept as history. It is my hope that my analysis and the evidence have put to rest a number of long-held beliefs.

First, the notion that the Old Burmese found on the Myazedi Inscriptions is the earliest example of written Burmese can no longer be sustained. Written Old Burmese is much older. Second, it has been demonstrated that 
written Old Burmese found in royal or elite stone inscriptions and commoner votive tablets also precedes the first dated evidence of written Old Mon in Burma by at least several decades, if not a century. Perhaps even more interesting, the widespread presence of commoner votive tablets written in Old Burmese probably shows that the vernacular was being written well before the first appearance of Kyanzittha's court Mon. This further augments the contention in Chapter Ten that Kyanzittha's reign was an anomaly, and not the starting point of a grand evolutionary scheme in which written Mon eventually begat written Burmese. It was the other way around: written Old Mon in Burma-the second phase of a process that actually began with written Old Burmese-was derived from the Old Burmese script, which in turn had been derived from the Pyū script. And finally, this evidence corresponds well with the best archaeological, epigraphic, and historical data and parallels the direction in which the earliest polities and urban civilization moved: from the agrarian interior to the commercial coasts. 